\title{
An Introduction to Beauvoir's "Other" Theory and an Application to the Contemporary Chinese Context
}

\author{
Qirui Jiang1,* \\ ${ }^{1}$ University of York \\ *Corresponding author. Email: Maolenin217@163.com
}

\begin{abstract}
In this article, we would start from illustrating some important points of her feminism philosophy, then examining it in a contemporary non-western culture, through which I want to prove that Beauvoir's philosophy still has its universal value. We will discuss Beauvoir's "Other" theory in three dimensions: firstly, we will generally illustrate her notion of "situation"; secondly, we will discuss, how women's subjectivity is shaped under their situations; thirdly, we will also explain her attitude on the issue of the body, which seems paradox in her theory. Thereafter, this article will examine how Beauvoir's "Other" theory can help us understand the gender issues in contemporary Chinese context.
\end{abstract}

Keywords: Beauvoir, feminism, "Other" Theory, gender issues in China

\section{INTRODUCTION}

Simone de Beauvoir is one of the most important philosophers in feminism. Some people take her as the mother of the second wave of feminism, as Carol Ascher (1987) describes that "she had been a kind of mother to millions of women of my generation - whose own mothers had spent the $40 \mathrm{~s}$ and $50 \mathrm{~s}$ being the good housewives....." (pp.107) Beauvoir, from the perspective of existentialism, develops a comprehensive theory on women's issue and starts a new era of the development of feminism theory.

However, critiques to Beauvoir's theory also exist and become sharper in later years. Some argue that her theory is out of date. For example, Natacha Polony discusses that The Second Sex's object has disappeared, given the social changes between Beauvoir's era and ours (Polony, 2007, pp. 30). Some argue the originality of her philosophy. Such as Margaret A. Simons, who considers that Beauvoir's opinions are not merely out-of-date, but also depends on Sartrean philosophy. (Simons, 1986, pp. 167).

However, these critiques seem not that fair to Beauvoir's theory. Firstly, Beauvoir's philosophy has not lost all its vitality in contemporary human society. Though based on limited historical and cultural background, it is more important that Beauvoir has offered us a theoretical structure which is still effective in contemporary, as Carol Ascher (1987) says: "There is no feminist theory that does not rest on hers; no questions we have yet asked that are not embedded in hers; no feminist scholarship that cannot be seen as filling in a dense picture she began." (pp. 109) Secondly, Beauvoir is not a totally blind adherent of Sartre. Notwithstanding, Beauvoir always starts from Sartrean philosophy; she offers important reformations to his points. For example, Beauvoir does not take subjectivity as autonomous as Sartre illustrated but puts it more under the influence of subjects' situations (Kruks, 1992, pp. 97-98).

Thus, we can still believe that Beauvoir's theory consistently has the theoretical value on its in today. In this article, we would start from illustrating some important points of her feminism philosophy, then examining it in a contemporary non-western culture, through which I want to prove that Beauvoir's philosophy still has its universal value. In the second part, we will discuss Beauvoir's "Other" theory in three dimensions: firstly, we will generally illustrate her notion of "situation"; secondly, we will discuss, how women's subjectivity is shaped under their situations; thirdly, we will also explain her attitude on the issue of the body, which seems paradox in her theory. Thereafter, in the third part, we will examine how Beauvoir's "Other" theory can help us understand the gender issues in contemporary China. 


\section{WOMAN AS “OTHER” - BEAUVOIR'S FEMINISM PHILOSOPHY}

Beauvoir starts her discussion in The Second Sex by asking and answering the question of "what is the woman?" In her view, in western culture, "female" is always the negative side of "male". In common sense, men usually not have the awareness to show their gender, but women always had to; in the semantic perspective, the words represent female in Latin also appears as a negative form; in the field of philosophy, the women are also be taken as human beings lacking certain virtues or organs, while similarly, in the psychological field, the pennies envy played an important character in a long time. (Beauvoir, 1949, pp. 25-26) Therefore, the female in human's narratives has always been recognized through comparison, but never directly from what she is in herself. Beauvoir (1949) says, in this way, the female exists as the "Other" of man:

"And she is nothing other than what man decides; she is thus called "the sex," meaning that the male sees her essentially as a sexed being; for him, she is sex, so she is it in the absolute. She is determined and differentiated in relation to man, while he is not in relation to her; she is the inessential in front of the essential. He is the Subject; he is the Absolute. She is the Other" (pp. 26)

Therefore, Beauvoir wants to figure out how women have been put into this position, and the following parts of the book mainly focus on offering an answer, which can be briefly concluded as: "One is not born, but rather becomes, woman.” (Beauvoir, 1949, pp. 328) We definitely cannot have a particular illustration of her comprehensive theory on "others" in limited pages here, so the best way for us to is to focus on some important points in her philosophy as follows.

\subsection{Situation - The Determinate Element in Woman's Formation}

Beauvoir's idea on the situation cannot be separated from Sartre's conception of "situation". In Sartre's view, though people are free, their freedom is not independent in the world, rather in the relationship with the surroundings of the subject (Sartre, 1993, pp. 482-483). In Sartre's view, the subject and the objectives relate with each other dialectically, the situation can sometimes be positive to the subject's aim, while sometimes be negative. Generally speaking, Sartre's situation can be categorized into five kinds: my position, my past, my surrounding, my neighbours, my death, from which we can find that in his mind, the situation is a very comprehensive conception (Du, 2009, pp. 144-150).
After denying the articulations on the differences between male and female from biology, psychology, and historical materialism, Beauvoir tries to discuss why a woman was formulated into what they like from the situation's perspective. Like Sartre, in Beauvoir, the situation also contains the subject and its objectives, but in categorizing the situation, she has some differences with Sartre.

Firstly, she mentions the body as an important part which formulates a woman's situation (Csajko, 2013; Bleie, 2019). Readers may feel confused about why Beauvoir suddenly pays attention to the body's issue when she at the same time keeps denying defining women's being "other" by biotic elements. Actually, there is no paradox here in my view. Beauvoir never says that there is no biotic difference between sexes, and what she means is that the biotic structure could not be endowed any value judgement. However, when we are going to understand women's situation, the body of them is actually an important part of their situation. The problem of the body would be discussed more specific later in the third point of this part.

Secondly, Beauvoir integrates Sartre's "position", "surrounding" and "neighbour" into "family". In Beauvoir's view, to most of the women before and in her era, most of their lives are spent inside the family. Even in modern society, when more and more women have their own jobs, they still have to spend more time in the family than men. In this situation, woman's relation to the society is reduced, they will more influence or be influenced by the society through their male partners in family - father, husband and son. Furtherly influenced by this situation, women will lose their possibility to fulfil or even image their own transcendental existence.

Thirdly, Beauvoir substitutes Sartre's "past" by "history". In her articulation, women's past does not appear individually, but as a continually intensifying process of being the "others". She uses a very long shoot on women's history, which even dates back to the primitive society of human beings to explain how women were fallen into a secondary position compared to men (Beauvoir, 1949, pp. 101). Beauvoir's important articulation to this history is how the appearance of private ownership intensified the suffering situation of women. In her view, when the property started to be divided to private, it becomes a symbol of the man's life. On the one hand, women were being taken as part of the property but not as human; while in the other hand, the fertility of women became the only way for the man to maintain their properties - they need sons to continue their transcendence in the properties (Beauvoir, 1949, pp. 117-119). Then, in these two reasons, women were tightly controlled by the men when the society stepped into private ownership. 


\subsection{Subjectivity -A Female Perspective}

There is no doubt that Beauvoir's subjectivity has a tight connection with Sartre's. In Sartre's philosophy, though existing in situations, the subject is entirely autonomous, because it can "always freely and autonomously [constitute] the meaning of its own situation through the capacity for transcendence." (Kruks, 1992, pp. 96) In this way, Sartre says that "the slave in chains is as free as his master", as he or she can choose "the meaning he gives his own situation." (Kruks, 1992, pp. 96) Nancy Hartsock considers this kind of subject as being in a "walled city", which is isolated in its own situation and holds a hostile attitude to others. She considers that this kind of subject is widely shared in class-struggle and masculinist narratives (Hartsock, 1985, pp. 241).

Though Beauvoir shares with Sartre the view that the universal freedom is the ultimate aim of all human beings as well as the individualism presupposition, she indeed cannot build up a feminism philosophy inside the Sartrean framework, as the "self" of which is quite different from the real experience of women (Kruks, 1992, pp. 97). Therefore, Beauvoir formulates a situated subject: "a subject that is intrinsically intersubjective and embodied, thus always 'interdependent' and permeable rather than walled" (Kruks, 1992, pp. 98). In this way, Beauvoir sharply points out how the women have existed during the long history until now: they never experience being absolute subjects, but always directly and sharply feel that they are socially constructed and live under the conditions that are always for men's advantages. Under this circumstance, the subjectivity of woman generally reflects some special characteristics. The first is immanence, which refers to a negative living situation of women. In Beauvoir, this immanence is opposite to the transcendence monopolized by men. Secondly, as men's wills deeply shape women's living situation, women's subjectivity also reflects dependence. Their subjective activities are all related to masculine society, which makes them unable to formulate their own transcendental will independently.

In Beauvoir's view, this situated subjectivity starts to change when women become economically independent in modern society. She says: "It is through work that woman has been able, to a large extent, to close the gap separating her from the male; work alone can guarantee her concrete freedom." (Beauvoir, 1949, pp. 813) When women can work directly in the society, they will be able to affirm their own subjects and, during their projects, they regain their transcendence (Beauvoir, 1949, pp. 813). However, this kind of freedom, in Beauvoir's opinions, are based on being exploited. The total social structure has not changed yet; most women still need to face the tough housework when they go back home, which means they usually hold double burden on their shoulder. This situation may make some women hesitate to seize the opportunities to fulfil their own transcendence; they may usually fall into a "bad faith", which means people always try to deceive themselves that they have no other choice, for they are afraid of the potential results of making a choice.

\subsection{Body - Weakness and Slavery}

We have mentioned that Beauvoir's attitude to the female body may seem ambiguous, as she is one way deny that women are born as "woman" due to their sexual characteristics, while in the other way considers that biotic elements play an important role in the formulation of the gender of women. In my opinion, the ambiguity happens because people may misunderstand the difference in two ways of comprehending biotic elements. Beauvoir denies the view that takes biotic elements as the transcendental causes of women's living condition. She firmly denies that a man is superior to a woman is due to his body. Nevertheless, Beauvoir also admits that biotic sexual difference is truth. The weakness of women in strength and their reproductive characteristic are two important factors of their situations.

Beauvoir articulates that, during the long history before private ownership became human's main structure, women's weakness in strength and during pregnancy made them need the protection of men (Beauvoir, 1949, pp. 97). In that period, men took the responsibility to hunt and overcome nature, which always faced the outside world, while women were confined inside the society or families to take on the inner tasks. Though in some periods, women were held up to a high position in religion, they never shared the real power of making rules for societies. In Beauvoir's view, this position was endowed by men who kept owning the power because of monopoly in violence (Beauvoir, 1949, pp. 122). After the private ownership was formulated in human history, as we have briefly discussed, women's situation became even worse. It is because bloodline is the most important element in the heritage of private properties. Therefore, under the private ownership society, women were under much tight control - men need to make sure their bloodline's "purity".

Even in modern society, women are still under the influence of the body. Beauvoir uses the example of the sex relationship to illustrate this point. Though women in contemporary already have the liberty to enjoy free sexual lives, they are still much more restricted than man. As a man is normally stronger in the body than a woman, he would not be afraid of being harmed when sharing sexes with an unfamiliar woman. However, when a man invited a woman, the situation would be 
quite different. When she and her sex partner whom she did not know very well, she may face the risk of being harmed when they are inside a private or covert environment, which is not only a suitable occasion for sex but also violence and crimes (Beauvoir, 1949, pp. 820-821)

\section{EXAMINING BEAUVOIR'S THEORY IN GENDER ISSUES OF CONTEMPORARY CHINESE SOCIETY}

In the formal part, we have illustrated several important points of Beauvoir's feminism philosophy. As we have said in the introduction, though some scholars think her theory is out-of-date, we still believe that her philosophical structure is valid in analyzing the phenomena of gender in contemporary society. In this part, we will try to prove this by using Beauvoir's philosophical structure to analyze and explain women's gender awareness in contemporary Chinese society. To contemporary China's issues, we cannot avoid the background of rural-urban binary structure, which will be our cultural context in our following discussion. In the paragraphs below, we would show how different situations between the rural and the urban shape the women.

Generally speaking, the gender awareness of Chinese women in recent decades shows its own characteristic. Scholars normally believe that with the time goes by, the identity to the traditional gender role will fall in both genders (Brewster and Padavic, 2000, pp. 477-487; Thornton and Young-DeMarco, 2001, pp. 1009-1037; Valentova, 2013, pp. 639-657) However, between 1990 and 2010, the gender awareness of Chinese women tend to go back to the traditional masculine ideology. According to the data from All-China Women's Federation and National Bureau of Statistics of China, women's identification rate to the opinion "men for society, women for society" has risen from $51.7 \%$ in 1990 to $71.9 \%$ in 2000 and $75.1 \%$ in 2010; the rate to "men have a better ability than women" rose from $29.4 \%$ in 1990 to $41 \%$ in 2000 ; meanwhile, to "good marriages are better than good jobs", the identification also inclined from the 2000s' $44 \%$ to the 2010s' 58.5\% (All-China Women's Federation and National Bureau of Statistics of China, 2011). Moreover, this phenomenon has different degree between the rural area and urban area. In some research, urban women have a much higher score than their rural sister in gender awareness (Feng and Xiao, 2014, pp. 112). We have all known that China has experienced an explosive development in economy and society in last 40 decades, then it will be a tough question for many scholars to explain why the gender consciousness, on the contrary, even fell back to the traditional attitude that has been suppressed during Mao's era. To this phenomenon, Beauvoir's theory can actually show its analyzing and explaining power.

We will first focus on the changes happened on rural women's situations. The most important inducement to rural women's situational transformation is the reform to the farmland system. In Mao's era, the private ownership of the field in rural China was abolished and the commune organized the farmers to perform collective agricultural production. During that period, the family was not the production unit in agriculture anymore, each farmer, no matter male or female, was the equal member of the commune (Hershatter, 2019). As the fields were owned and cultivated together by the commune, agriculture mechanization was the mainstream in that period. However, in the post-Mao era, the collective agriculture totally dissolved around most part of China, which is substituted by the household contract responsibility system. The latter is an agricultural system organized on the family unit, which means the right of use of the field was divided to each family. Though the ownership still belongs to the state, agriculture is actually organized by small families. This change firstly slowed the mechanization in rural area, as the large machine cannot fit into the small pieces of land contracted by single-family, which can be proved by that the sales of Dongfanghong tractors dropped from 24000 to less than 10000 between 1980 and 1981 (Xinhua Net, 2018). This situation critically weakens women's productive role in the rural area. In the commune, as the machines were used in a high rate, though women are weak in strength, they were still able to have better productivity than men. Nonetheless, after the reform, the agriculture fell back to rely more on manual labour, women's disadvantage in strength was exposed again. As a result, many women became secondary to their husband in the family. Though many rural people are going to urban areas to earn money, it makes no sense in relieving the situation. Firstly, in most families, the females are left in the countryside to hold the family while the husband does the tough works in cities. In this kind of family, the wives would rely much more on the husband, as they play even the monopoly role in the family's economic source. Secondly, though the couple goes to the city together in some families, the difference of the salaries may devote to increasing the inequality inside the family (Liu, Meng and Zhang, 2000, pp. 347).

Secondly, the culture in rural China also changed a lot in post-Mao eras. As the commune was dissolved and the public economic system changed, the rural area's socialism culture lost its root. In Mao's era, the mobile film projection in rural place played an important role in the collectivity's cultural lives. Though it was always seen as a propaganda machine, it played a positive role in promoting gender awareness (Chen, 2003, pp. 183). Nevertheless, when the collective economy dissolved in rural areas, the grassroots institutions' functions were also weakened, the cultural power gradually slipped back to the hands of clans. This 
is because when the private economy revived in rural places, the traditional culture which stresses on bloodline became strong again. Therefore, in the rural society, the dominant role of husband and discrimination to daughter gradually becomes strong again. Therefore, this cultural transformation makes the chains of patriarchy even heavier on the shoulders of rural women. Not only suffering the weakening of their economic role but also losing the support in culture, women in rural place very easily fall to "bad faith" as Beauvoir has described. Under this situation, the believers to Christian in Chinese rural women have a huge increment in recent decades. Religion, especially Christian and Buddhism which point to "the other side", becomes the way for the rural women relieving their sufferings on "this side". This reflects that they, in some extents, surrendered to the situation of being dominated by the masculine society.

In the city area, the general situation for women is better than their rural sisters. From an economic perspective, most urban people still work in companies or governments and are paid by salaries. Therefore, women can have a relatively equal economic situation compared to their partners. Besides, there are more low body-required works in urban areas than in the countryside. The weakness in strength or other body conditions though may still influence women's choices, but still, leave enough opportunities for them to be economically independent. In the political perspective, though the only-child policy is interference to mothers, it benefits the daughters. This policy was performed much stricter in an urban area than in rural area; thus, the urban daughter is always the only heir of the properties of the family, she would not be seen as a foil of boys in her own family. In a cultural perspective, as the political power in the urban areas is more efficient and have more channels to perform its influence, the modern values propagated the state are rooted more deeply in urban citizens minds. For example, the urban child normally has more formal and systemic education in school, through which they are not only taught knowledge but also trained in moralities and values.

However, what we have mentioned only means that women are more able to be independent than their rural sisters, it does not mean that they can already fulfil their transcendence as free as they wish. Though there are more jobs in the urban area that have less requirement on the body, women are still discriminated because of their body. This is because many companies consider that if the female employer got pregnant, they would have to pay them salaries during their maternity leaves and the work efficiency during pregnancy would also decline (Stevenson and Chen, 2019). Therefore, a woman is usually beaten by her male competitors in the interviews; even she has the same or even better conditions.
In the cultural area, the narratives of women also reflect men's requirement on the female. In Mao's era, women's aesthetic was based on a heroical narrative, which encouraged women to be heroin or to be steely (Wu, 2009, pp. 71). However, since the 1980s, in the public narratives, women's beauty has increasingly related to the sexual characteristic ( $\mathrm{Wu}, 2009$, pp. 80). More and more advertisements - like "loving your breast is loving yourself" from a breast enhancement advertisement - appear during this period. From an interview of South China Morning Post on plastic surgery, all interviewees say that society requires them to become beautiful, but they also reflect that society never requires a man to be handsome (South China Morning Post, 2018). This masculine aesthetic also combines with the masculine power in the society, in the employment market, beauty more and more becomes a resource (Stauffer, 2018, pp. 30-36). Under this situation, for fulfilling their expectation in career or owning a better life through a good marriage, some of the women surrender to the man-dominating sexual aesthetic and try to use her sexual resource to trade for better lives.

\section{CONCLUSION}

In this article, we have discussed the main philosophical structure of Simone de Beauvoir on how women become women, or how female "gender" formulates. We firstly illustrate her theory on the situation and show how it influences women. Then, we focus on how women's special subjectivity is formulated in their situation and the characteristics of this situated subjectivity. Finally, we explain what role the notion of "body" plays in her philosophy. After that, we examine Beauvoir's theory in the context of contemporary society. On the one hand, we want to show, the philosophical structure of Beauvoir can be valid in a non-western cultural context; on the one hand, we also want to find a way to explain why the traditional gender awareness gains a large increment during the economic and social development of China. In the third part, based on the historical materials and data, we offer a valid and reliable analysis inside Beauvoir's structure. Therefore, Beauvoir's philosophical structure in feminism is not yet totally out of validity no matter in contemporary society or a non-western culture.

\section{REFERENCES}

[1] All-China Women's Federation and National Bureau of Statistics of China (2011). Report on Major Results of the Third Wave Survey on The Social Status of Women in China. [online] www.china.com.cn. Available at http://www.china.com.cn/zhibo/zhuanti/ch-xinwen/ 2011-10/21/content_23687810.htm.

[2] Ascher, C. (1987). Simone de Beauvoir. Mother of 
Us All. Social Text, (17), pp.107-109.

[3] Bleie, T. (2019). The Body as Situation: A Darwinian Reading ofThe Second Sex. NORA Nordic Journal of Feminist and Gender Research, 27(1), pp.54-71.

[4] Brewster, K.L. and Padavic, I. (2000). Change in Gender-Ideology, 1977-1996:The Contributions of Intracohort Change and Population Turnover. Journal of Marriage and Family, 62(2), pp.477487.

[5] Chen, T.M. (2003). Propagating the Propaganda Film: The Meaning of Film in Chinese Communist Party Writings, 1949-1965. Modern Chinese Literature and Culture, [online] 15(2), pp.154-193. Available at: https://www.jstor.org/stable/41490907?seq=1\#meta data_info_tab_contents [Accessed 14 Jan. 2021].

[6] Csajko, K. (2013). Beauvoir and Woman's Situation: Context and Women's Bodies in The Second Sex. In: American Political Science Association 2013 Annual Meeting. Available at SSRN: https://ssrn.com/abstract=2303476.

[7] De Beauvoir, S. (1949). The Second Sex. Translated by C. Borde. and Translated by S. Malovany-Chevallier. Vintage Classics.

[8] Du, X. (2009). Sa Te Ying Lun. Beijing: The Commercial Press.

[9] Feng, X. and Xiao, J. (2014). Zhongguo Nüxing Xingbie Juese Yishi De Chengxiang Chayi Yanjiu. The Journal of Humanities, 2014(11), pp.107-116.

[10] Hershatter, G. (2019). Women and China's Socialist Construction, 1949-78. [online] The Asia-Pacific Journal: Japan Focus. Available at: https://apjjf.org/2019/12/Hershatter.html [Accessed 14 Jan. 2021].

[11] Kruks, S. (1992). Gender and Subjectivity: Simone de Beauvoir and Contemporary Feminism. Signs: Journal of Women in Culture and Society, 18(1), pp.89-110.

[12] Liu, P.-W., Meng, X. and Zhang, J. (2000). Sectoral gender wage differentials and discrimination in the transitional Chinese economy. Journal of Population Economics, [online] 13(2), pp.331-352. Available

at: https://link.springer.com/article/10.1007/s00148005 0141.

[13] Polony, N. (2007). L' homme est l'avenir de la femme: autopsie du féminisme contemporain. Paris: Lattès.

[14] Sartre, J.-P. (1993). Being and Nothingness.
Translated by H.E. Barnes. New York: Washington Square Press.

[15] Schwarzer, A. and Simone De Beauvoir (1984). After The second sex : conversations with Simone De Beauvoir. New York: Pantheon Books.

[16] Simons, M.A. (1986). Beauvoir and Sartre: The Philosophical Relationship. special issue of Yale French Studies, (72), p.165.

[17] South China Morning Post (2018). Why Chinese women spend fortunes on plastic surgery. YouTube. Available https://www.youtube.com/watch? $\mathrm{v}=\mathrm{mVpAOr6GY}$ Cs.

[18] Stauffer, B. (2018). "Only Men Need Apply" Gender Discrimination in Job Advertisements in China. [online] Human Rights Watch. Available at: https://www.hrw.org/report/2018/04/23/only-men-n eed-apply/gender-discrimination-job-advertisement s-china.

[19] Stevenson, A. and Chen, E. (2019). In China, Working Mothers Say They Are Fired or Sidelined. The New York Times. [online] 1 Nov. Available at: https://www.nytimes.com/2019/11/01/business/chin a-mothers-discrimination-working-.html.

[20] Thornton, A. and Young-DeMarco, L. (2001). Four Decades of Trends in Attitudes Toward Family Issues in the United States: The 1960s Through the 1990s. Journal of Marriage and Family, 63(4), pp.1009-1037.

[21] Valentova, M. (2013). Age and sex differences in gender role attitudes in Luxembourg between 1999 and 2008. Work, Employment and Society, 27(4), pp.639-657.

[22] Wu, P. (2009). From 'Iron Girl' to 'Sexy Goddess':An Analysis of the Chinese Media. In: P. Markula, ed., Olympic Women and the Media: International Perspectives. Palgrave Macmillan UK.

[23] Xinhua Net (2018). Gongheguo Nongji Gongye "Zhangzi" Chengzhangji. [online] www.xinhuanet.com. Available at: http://www.xinhuanet.com/2018-07/21/c_11231589 51.htm [Accessed 14 Jan. 2021]. 